\title{
KERJASAMA PEGAWAI DALAM MEMBERIKAN PELAYANAN DI DINAS KEPENDUDUKAN DAN CATATAN SIPIL KABUPATEN BOALEMO
}

\author{
Andi Yusuf Katili \\ STIA Bina Taruna Gorontalo \\ yusuf2801@gmail.com
}

\begin{abstract}
ABSTRAK
Tujuan penelitian ini adalah untuk mengetahui bagaimana kerjasama pegawai dalam memberikan pelayanan di Dinas Kependudukan Dan Catatan Sipil Kabupaten Boalemo. Jenis penelitian ini adalah penelitian deskriptif dengan teknik analisis kuantitatif melalui instrumen pengukuran skala Likert 5 (lima). Variabel penelitian dioperasionalkan melalui tiga (3) indikator yaitu: motivasi, koordinasi dan komunikasi, dan pemantauan. Data diperoleh melalui penyebaran kuesioner 28 (dua puluh delapan) responden, karyawan di Dinas Kependudukan dan Catatan Sipil Kabupaten Boalemo. Berdasarkan analisis dari hasil yang diperoleh dengan kesimpulan sebagai berikut: Indikator motivasi memperoleh skor rata-rata 2,47 termasuk kategori, yang berarti bahwa motivasi kerja sama karyawan dalam memberikan layanan bernilai kurang. Indikator koordinasi dan komunikasi memperoleh skor rata-rata 2,77, termasuk kategori sedang, berarti koordinasi dan komunikasi sebagai bentuk kemitraan sipil dalam memberikan layanan bernilai kurang. Indikator pemantauan memperoleh skor rata-rata 2,68, termasuk kategori, yang berarti bahwa pengawasan bersama karyawan dalam memberikan layanan bernilai lebih rendah. Secara keseluruhan skor rata-rata diperoleh oleh kategori 2,64, yang berarti bahwa kerjasama karyawan dalam menyediakan layanan distrik Departemen Kependudukan dan Catatan Sipil dinilai kurang. Selanjutnya, disarankan bahwa: penghargaan atas prestasi karyawan, membina hubungan kerja membutuhkan perhatian serius kepada karyawan yang termotivasi untuk bekerja sama dalam memberikan layanan. Peran kepemimpinan sangat diperlukan untuk membangun koordinasi dan komunikasi antar karyawan dalam memberikan layanan kepada masyarakat. Objektivitas dan kontinuitas pengawasan perlu ditingkatkan untuk mencegah isu-isu yang diketahui terutama mengenai pelayanan kepada publik.
\end{abstract}

\section{Kata Kunci: Kerjasama, Pegawai, Pelayanan, Disdukcapil}

\section{PENDAHULUAN}

Masalah pelayanan semakin berkembang menjadi isu sentral yang memerlukan penataan sistem administrasi dan sistem pembuatan kebijakan yang lebih partisipatoris. Itulah sebabnya gerakan reformasi menjadi komitmen kolektif masyarakat Indonesia untuk mendorong pemerintah menciptakan 
kebijakan pelayanan yang semakin baik dan memihak kepada kepentingan masyarakat. Tuntutan masyarakat terhadap peningkatan kualitas pelayanan juga didasarkan pada kondisi pelayanan yang diberikan oleh aparatur pemerintah dalam berbagai instansi, yang dirasakan belum sesuai dengan harapan dan kebutuhan masyarakat, dimana pelayanan birokrasi yang diberikan pemerintah masih kurang produktif dan masih jauh dari harapan publik (masyarakat).

Pemerintahan dengan segala perangkatnya sebagai pilar utama penyelenggara pelayanan publik semakin dihadapkan pada kompleksitas pelayanan yang sesuai dengan tuntutan masyarakat. Untuk itu peranannya harus mampu mengakomodasi segala bentuk perubahan dan tanggap terhadap gejala-gejala yang timbul di masyarakat agar tercipta hubungan yang harmonis dan terpupuknya kepercayaan masyarakat terhadap pemerintah.

Pelayanan yang berkualitas atau pelayanan prima dapat dilakukan dengan baik manakala didukung oleh kinerja yang baik dan berkualitas dari para pegawai sebagai aparat pemerintah yang bertugas memberi pelayanan. Kinerja yang baik ini akan dicapai apabila para pegawai mampu bekerjasama dalam melaksanakan pekerjaannya dalam rangka memberikan pelayanan yang berkualitas. Kerjasama yang baik akan tercipta apabila terdapat pengorganisasian pekerjaan yang terorganisasi dan terarah, yang kemudian ditunjang oleh kemampuan individu pegawai dalam melaksanakan pekerjaannya.

Kerjasama merupakan bagian terpenting dari seluruh proses pelaksanaan tugas dan fungsi pemerintah sebagai pemberi pelayanan kepada masyarakat. Kerjasama tidak lahir dengan sendirinya tetapi membutuhkan wadah dan pengarahnya, dalam hal ini organisasi atau instansi merupakan wadah lahirnya kerjasama, karena dalam organisasi atau instansi memiliki kegiatan yang kompleks sehingga membutuhkan peran dari setiap anggota atau pegawai di dalamnya untuk melaksanakannya. Organisasi atau instansi juga memiliki para pegawai yang tingkat kemampuan, sifat, perilaku, dan latar belakangnya beraneka ragam, sehingga dibutuhkan pengarah yang biasanya diperankan oleh pimpinan yang memiliki kecerdasan dan ketajaman analisa sehingga mampu mengorganisir seluruh pegawainya untuk bersama-sama melakukan pekerjaan dengan baik dan saling mengisi kekurangan. 
Kerjasama para pegawai dalam suatu instansi pemerintah sangat penting dalam melaksanakan tugas pelayanan kepada masyarakat. dengan adanya kerjasama yang baik, maka seluruh pekerjaan pelayanan dapat diselesaikan dengan baik pula dan akan memberikan out-put yang memuaskan bagi penerima layanan (masyarakat). Namun pada realitasnya, kerjasama merupakan hal klise yang hanya menjadi perbincangan dan tameng bagi para pegawai sebagai aparat pemerintah, karena pada kenyataannya kerjasama terbentuk manakala masing-masing individu memiliki tendensi atau kepentingan sendiri dan bukan didasarkan atas kepentingan organisasi.

Demikian halnya fenomena yang dapat dilihat pada salah satu instansi pemerintah di Kabupaten Boalemo, yaitu Dinas Kependudukan dan Catatan Sipil. Pada instansi ini, belum nampak kerjasama pegawai yang baik dalam memberikan pelayanan kepada masyarakat. hal ini tercermin melalui perilaku para pegawai yang terkesan individualis dan mementingkan nama baik dirinya atau bidang kerjanya saja, sering menghindar atau mengelak apabila diminta memberikan pelayanan yang bukan tugas bidang kerjanya, kurangnya jalinan koordinasi dan komunikasi kerja yang baik menyebabkan pemberian pelayanan kepada masyarakat juga kurang memuaskan. Masalah lainnya adalah menyangkut rendahnya disiplin para pegawai sehingga tugas pelayanan sering terbebankan pada beberapa orang pegawai saja, dan akhirnya menimbulkan kecemburuan sosial di antara pegawai. Kurangnya kerjasama pegawai dalam memberikan pelayanan ini juga disebabkan oleh kurangnya wawasan dan pemahaman tentang tanggung jawab bersama untuk menjaga citra organisasi, akibat tingkat pendidikan sebagian besar para pegawai yang relatif rendah, sehingga kemampuannya untuk menjabarkan makna dalam tugas dan fungsinya juga masih relatif rendah. Permasalahan ini terus berlanjut disebabkan pula oleh kurang ketatnya pengawasan, pengarahan dan pembinaan dari pimpinan terhadap aktivitas para pegawainya. Berbagai permasalahan tersebut di atas merupakan hal penting yang harus segera diatasi untuk menjaga citra organisasi dimata masyarakat sebagai penerima pelayanan, di samping untuk menciptakan hubungan kerja dan lingkungan kerja yang kondusif dan harmonis sebagai jaminan akan kenyamanan para pegawai melaksanakan pekerjaannya. 
Dinas Kependudukan dan Catatan Sipil Kabupaten Boalemo sebagai salah satu instansi yang memiliki hubungan langsung dengan masyarakat dalam memberikan berbagai pelayanan misalnya pelayanan akta kelahiran, akta kematian, kartu keluarga, KTP, dan surat-surat keterangan lainnya yang berhubungan dengan kependudukan. Dalam memberikan pelayanan ini diharapkan terjalin kerjasama para pegawai sehingga menghasilkan pelayanan yang memuaskan bagi masyarakat sebagai tujuan utamanya, yaitu memberikan pelayanan prima yang memuaskan dan berkualitas kepada masyarakat.

\section{PERMASALAHAN}

Berdasarkan identifikasi masalah yang ada maka peneliti merumuskan masalah sebagai berikut: Apakah kerjasama pegawai dalam memberikan pelayanan di Dinas Kependududkan dan Catatan Sipil Kabupaten Boalemo telah berlangsung dengan baik.

\section{TUJUAN DAN MANFAAT PENELITIAN}

\section{Tujuan Penelitian}

Adapun Tujuan yang hendak dicapai dalam penelitian ini adalah untuk mengetahui tentang kerjasama pegawai dalam memberikan pelayanan di Dinas Kependududkan dan Catatan Sipil Kabupaten Boalemo.

\section{Manfaat Penelitian}

Adapun manfaat yang diharapkan peneliti dalam penelitian ini adalah sebagai berikut:

\section{Secara Teoritis}

1. Menjadi bahan masukan bagi pengembangan ilmu pengetahuan khususnya bidang pelayanan publik.

2. Menjadi bahan kajian lanjutan maupun referensi bagi penelitian lanjutan khususnya mengenai kerjasama pegawai dalam memberikan pelayanan kepada masyarakat.

\section{Secara Praktis}

1. Menjadi bahan masukan bagi pemerintah daerah Kabupaten Boalemo secara umum untuk meningkatkan kerjasama para pegawai dalam memberikan pelayanan yang berkualitas kepada masyarakat.

2. Menjadi bahan masukan sekaligus bahan evaluasi khususnya bagi Dinas Kependudukan dan Catatan Sipil Kabupaten Boalemo dalam usaha memperbaiki jalinan kerjasama pegawai dalam memberikan pelayanan. 


\section{METODE PENELITIAN}

Jenis penelitian ini adalah penelitian survey dengan menggunakan pendekatan metode deskriptif kuantitatif. Penelitian ini difokuskan pada satu variabel yaitu "kerjasama pegawai dalam memberikan pelayanan". Selanjutnya variabel penelitian ini akan diukur dengan menggunakan operasional variabel atau indikator penelitian sebagai tolok ukurnya. terdiri dari: motivasi, koordinasi dan komunikasi, serta pengawasan. Populasi dalam penelitian ini terdiri dari seluruh Pegawai Negeri Sipil di lingkungan Dinas Kependudukan dan Catatan Sipil Kabupaten Boalemo, yaitu sebanyak 28 (dua puluh delapan) orang.

Sumber data dalam penelitian terdiri dari data primer dan data sekunder, yaitu: (1) Data Primer; adalah data yang diperoleh secara langsung dari responden melalui pengisian daftar kuesioner dan wawancara; dan (2) Data Sekunder; adalah data pendukung yang diperoleh melalui kegiatan mengamati, menganalisa dan mencatat dokumen-dokumen yang berhubungan dengan penelitian.

Sedangkan tehnik yang digunakan untuk mengumpulkan data dalam penelitian ini, adalah: observasi, kuesioner dan dokumentasi.

Teknik analisis yang akan digunakan adalah analisis statistik deskriptif dengan menggunakan alat ukur skala likert bergradasi 5 (lima)

\section{HASIL PENELITIAN DAN PEMBAHASAN}

Penelitian ini terdiri dari satu variabel atau variabel tunggal yaitu kerjasama pegawai dalam memberikan pelayanan, yang dilakukan di Dinas Kependudukan dan Catatan Sipil Kabupaten Boalemo. Variabel penelitian ini diukur dengan menggunakan 3 (tiga) indikator yang terdiri dari: (1) Motivasi, (2) Koordinasi dan Komunikasi, dan (3) Pengawasan.

Ketiga indikator tersebut dituangkan ke dalam instrumen penelitian berupa daftar pertanyaan (kuisioner) sebanyak 9 (sembilan) pertanyaan dengan 5 (lima) gradasi, dan disebarkan kepada 28 orang responden.

\section{Indikator Motivasi}

Motivasi dalam penelitian ini adalah dorongan bagi setiap pegawai di Dinas Kependudukan dan Catatan Sipil Kabupaten Boalemo yang menggerakkan dan mengarahkan sikap dan perilaku kerjasama yang terbentuk dengan adanya motivasi melalui adanya penghargaan/pengakuan atas hasil kerja, hubungan kerja, dan kepuasan kerja. 
Dimana dapat digambarkan bahwa penghargaan/pengakuan atas hasil pekerjaan pegawai adalah $0 \%$ berada dalam kategori sangat sesuai; $17,14 \%$ berada dalam kategori sesuai; $28,57 \%$ berada dalam kategori ragu-ragu; 50,00\% berada dalam kategori tidak sesuai; dan $14,29 \%$ berada dalam kategori sangat tidak sesuai.

Selanjutnya diperoleh nilai skor rata-rata sebesar 2,28 yang apabila dimasukkan dalam skala range penilaian berada dalam tingkatan rendah. Dengan demikian dapat dikatakan bahwa penghargaan/pengakuan yang diterima pegawai Dinas Kependudukan dan Catatan Sipil Kabupaten Boalemo dalam melaksanakan pekerjaannya dinilai tidak sesuai.

Dimana dapat digambarkan bahwa kesesuaian hubungan kerja pegawai adalah $7,14 \%$ berada dalam kategori sangat sesuai; $17,86 \%$ berada dalam kategori sesuai; 28,57 $\%$ berada dalam kategori ragu-ragu; $32,14 \%$ berada dalam kategori tidak sesuai; dan $14,29 \%$ berada dalam kategori sangat tidak sesuai.

Selanjutnya diperoleh nilai skor rata-rata sebesar 2,71 yang apabila dimasukkan dalam skala range penilaian berada dalam tingkatan sedang. Dengan demikian dapat diartikan bahwa hubungan kerja pegawai di lingkungan Dinas Kependudukan dan Catatan Sipil Kabupaten Boalemo sebagai upaya kerjasama dalam memberikan pelayanan dinilai kurang.

Dimana dapat digambarkan kesesuaian kepuasan kerja pegawai adalah $0 \%$ berada dalam kategori sangat sesuai; $17,86 \%$ berada dalam kategori sesuai; $28,57 \%$ berada dalam kategori ragu-ragu; 32,14\% berada dalam kategori tidak sesuai; dan $21,43 \%$ berada dalam kategori sangat tidak sesuai.

Selanjutnya diperoleh nilai skor rata-rata sebesar 2,43 yang apabila dimasukkan dalam skala range penilaian berada dalam tingkatan sedang. Dengan demikian dapat diartikan bahwa kepuasan kerja pegawai di lingkungan Dinas Kependudukan dan Catatan Sipil Kabupaten Boalemo dalam upaya kerjasama memberikan pelayanan dinilai kurang.

\section{Indikator Koordinasi dan} Komunikasi

Yang dimaksud dengan koordinasi dan komunikasi dalam penelitian ini adalah bentuk kerjasama antara sesama pegawai maupun antara pegawai dengan pimpinan. Koordinasi dan komunikasi yang baik akan menjalin suatu bentuk kerjasama melalui proses pengintegrasian dan 
penyampaian informasi menyangkut tugas pekerjaan antara seluruh pegawai di Dinas Kependudukan dan Catatan Sipil Kabupaten Boalemo, dalam upaya memberikan pelayanan maksimal kepada masyarakat.

Dimana dapat digambarkan kesesuaian koordinasi antara pegawai adalah $14,29 \%$ berada dalam kategori sangat sesuai; $17,86 \%$ berada dalam kategori sesuai; $32,14 \%$ berada dalam kategori ragu-ragu; $35,71 \%$ berada dalam kategori tidak sesuai; dan $0 \%$ berada dalam kategori sangat tidak sesuai.

Selanjutnya diperoleh nilai skor rata-rata sebesar 2,75 yang apabila dimasukkan dalam skala range penilaian berada dalam tingkatan sedang. Dengan demikian dapat diartikan bahwa koordinasi antara pegawai di lingkungan Dinas Kependudukan dan Catatan Sipil Kabupaten Boalemo dalam upaya kerjasama memberikan pelayanan dinilai kurang.

Dimana dapat digambarkan kesesuaian komunikasi antara pegawai adalah $14,29 \%$ berada dalam kategori sangat sesuai; $17,86 \%$ berada dalam kategori sesuai; $35,71 \%$ berada dalam kategori ragu-ragu; $32,14 \%$ berada dalam kategori tidak sesuai; dan $0 \%$ berada dalam kategori sangat tidak sesuai.
Selanjutnya diperoleh nilai skor rata-rata sebesar 2,79 yang apabila dimasukkan dalam skala range penilaian berada dalam tingkatan sedang. Dengan demikian dapat diartikan bahwa komunikasi antara pegawai di lingkungan Dinas Kependudukan dan Catatan Sipil Kabupaten Boalemo dalam upaya kerjasama memberikan pelayanan dinilai kurang.

\section{Indikator Pengawasan}

Pengawasan dalam penelitian ini adalah suatu tugas yang dilakukan oleh pimpinan untuk menilai kesesuaian pekerjaan para pegawai pada berbagai bidang dan berbagai tingkatan jabatan. Pengawasan harus dilakukan secara objektif dan kontinyu atas kerjasama yang dilakukan oleh seluruh pegawai dalam rangka memberika pelayanan yang baik kepada masyarakat.

Dimana dapat digambarkan kesesuaian objektivtas pengawasan adalah $0 \%$ berada dalam kategori sangat sesuai; $17,86 \%$ berada dalam kategori sesuai; $35,71 \%$ berada dalam kategori ragu-ragu; 32,14\% berada dalam kategori tidak sesuai; dan $14,29 \%$ berada dalam kategori sangat tidak sesuai.

Selanjutnya diperoleh nilai skor rata-rata sebesar 2,57 yang apabila dimasukkan dalam skala range penilaian berada dalam 
tingkatan sedang. Dengan demikian dapat diartikan bahwa objektivitas pengawasan terhadap kerjasama pegawai di lingkungan Dinas Kependudukan dan Catatan Sipil Kabupaten Boalemo dalam memberikan pelayanan dinilai kurang.

Dimana dapat digambarkan kesesuaian kontinyuitas pengawasan adalah $0 \%$ berada dalam kategori sangat sesuai; $28,57 \%$ berada dalam kategori sesuai; $35,71 \%$ berada dalam kategori ragu-ragu; 21,43\% berada dalam kategori tidak sesuai; dan $14,29 \%$ berada dalam kategori sangat tidak sesuai.

Selanjutnya diperoleh nilai skor rata-rata sebesar 2,79 yang apabila dimasukkan dalam skala range penilaian berada dalam tingkatan sedang. Dengan demikian dapat diartikan bahwa kontinyuitas pengawasan terhadap kerjasama pegawai di lingkungan Dinas Kependudukan dan Catatan Sipil Kabupaten Boalemo dalam memberikan pelayanan dinilai kurang.

AKUMULASI ANALISIS HASIL PENELITIAN

\begin{tabular}{|c|c|c|c|}
\hline No & Indikator Penelitian & Skor & Kategori \\
\hline \multicolumn{4}{|c|}{ Motivasi } \\
\hline 1 & $\begin{array}{l}\text { Kesesuaian } \\
\text { penghargaan/pengakuan atas } \\
\text { hasil kerja pegawai }\end{array}$ & 2,28 & Rendah \\
\hline 2 & $\begin{array}{l}\text { Kesesuaian hubungan kerja } \\
\text { pegawai }\end{array}$ & 2,71 & Sedang \\
\hline \multirow[t]{2}{*}{3} & $\begin{array}{l}\text { Kesesuaian kepuasa kerja } \\
\text { pegawai }\end{array}$ & 2,43 & Sedang \\
\hline & Rata-Rata & 2,47 & Sedang \\
\hline \multicolumn{4}{|c|}{ Koordinasi dan Komunikasi } \\
\hline 4 & $\begin{array}{l}\text { Kesesuaian koordinasi antara } \\
\text { pegawai }\end{array}$ & 2,75 & Sedang \\
\hline \multirow[t]{2}{*}{5} & $\begin{array}{ll}\text { Kesesuaian } & \text { komunikasi } \\
\text { antara pegawai } & \end{array}$ & 2,79 & Sedang \\
\hline & Rata-Rata & 2,77 & Sedang \\
\hline \multicolumn{4}{|c|}{ Pengawasan } \\
\hline 7 & $\begin{array}{l}\text { Kesesuaian } \\
\text { pengawasan }\end{array}$ & 2,57 & Sedang \\
\hline
\end{tabular}


Publik: Jurnal Manajemen Sumber Daya Manusia, Administrasi dan Pelayanan Publik Sekolah Tinggi Ilmu Administrasi Bina Taruna Gorontalo Volume II Nomor 2 Desember 2015

\begin{tabular}{|c|lr|c|c|}
\hline 8 & $\begin{array}{l}\text { Kesesuaian } \\
\text { pengawasan }\end{array}$ & 2,79 & Seding \\
\hline & Rata-Rata & $\mathbf{2 , 6 8}$ & Sedang \\
\hline & $\begin{array}{l}\text { RATA-RATA } \\
\text { SKOR }\end{array}$ & TOTAL & $\mathbf{2 , 6 4}$ & Sedang \\
\hline
\end{tabular}

\section{Indikator Motivasi}

Berdasarkan akumulasi analisis hasil penelitian sebagaimana yang telah disajikan sebelumnya untuk indikator motivasi diperoleh skor rata-rata sebesar 2,47. Nilai skor rata-rata ini apabila dimasukkan ke dalam skala range penilaian berada pada kategori sedang, berarti bahwa motivasi pegawai untuk bekerjasama dalam memberikan pelayanan di Dinas Kependudukan dan Catatan Sipil Kabupaten Boalemo dinilai kurang.

Jika dihubungkan dengan pengamatan peneliti atas kondisi riil yang terjadi di lingkungan Dinas Kependudukan dan Catatan Sipil Kabupaten Boalemo, hasil penelitian tersebut adalah sesuai. dikatakan demikian, sebab sebagian besar pegawai terkesan menghindar, tidak peduli, dan saling melempar tanggung jawab jika ada masyarakat yang membutuhkan pelayanan misalnya pelayanan akta kelahiran, Kartu Tanda Penduduk (KTP), maupun pelayanan lain yang berhubungan dengan kependudukan dan catatan sipil lainnya. Hal ini disebabkan oleh kurangnya penghargaan atau pengakuan atas hasil kerja yang telah dilakukan pegawai, kurang baiknya hubungan kerja sesama pegawai dalam memberikan pelayanan, serta rendahnya kepuasan pegawai atas pekerjaan yang dilakukannya.

Hal tersebut di atas memicu timbulnya sikap individualis dan apatis pegawai atas tugas pekerjaan yang menjadi tanggung jawabnya. Selanjutnya sikap ini menyebabkan rendahnya motivasi pegawai untuk bekerjasama dalam memberikan pelayanan yang sudah menjadi kewajibannya sebagai pegawai di lingkungan Dinas Kependudukan dan Catatan Sipil Kabupaten Boalemo.

Kurangnya motivasi pegawai untuk bekerjasama dalam memberikan pelayanan ini akan menyebabkan terbentuknya citra buruk instansi sebagai organsiasi pemerintah yang memberikan pelayanan kepada publik dan menganut asas pelayanan prima yang 
selama ini menjadi prinsip pemerintah dalam memberikan pelayanan. Oleh sebab itu, perlu adanya perhatian serius untuk meningkatkan motivasi pegawai oleh pimpinan instansi dengan memberikan penghargaan (reward) atau pengakuan atas prestasi kerja pegawai, memberikan bimbingan dan arahan sehingga pegawai dapat membina hubungan kerja yang lebih baik, sehingga akan terjalin kerjasama ke arah yang baik dalam kerangka memberikan pelayanan kepada publik/masyarakat.

\section{Indikator Koordinasi dan \\ Komunikasi}

Berdasarkan akumulasi analisis hasil penelitian sebagaimana yang telah disajikan sebelumnya untuk indikator koordinasi dan komunikasi diperoleh skor rata-rata sebesar 2,77. Nilai skor rata-rata ini apabila dimasukkan ke dalam skala range penilaian berada pada kategori sedang, berarti bahwa koordinasi dan komunikasi pegawai untuk membangun kerjasama dalam memberikan pelayanan di Dinas Kependudukan dan Catatan Sipil Kabupaten Boalemo dinilai kurang.

Penilaian ini sebagaimana gambaran yang diperoleh melalui pengamatan peneliti bahwa antara satu pegawai dengan pegawai lainnya kurang terdapat koordinasi dan komunikasi yang baik dalam rangka kerjasama memberika pelayanan kepada masyarakat. Misalnya dalam hal menangani atau melayani permohonan penerbitan akta kelahiran maupun keterangan yang menyangkut kependudukan dan catatan sipil lainya yang diajukan masyarakat, dimana kelengkapan administrasi permohonannya kurang lengkap, para pegawai tidak saling berkoordinasi dan berkomunikasi sehingga sering timbul masalah dalam pembukuan atau pengarsipan kelengkapan berkas permohonan dari masyarakat. Disamping itu, kurangnya koordinasi dan komunikasi ini juga tampak pada sikap kerja pegawai yang terkesan individualis dan tidak peduli dengan pekerjaan pegawai lainnya. Kurangnya sikap kepedulian ini menyebabkan kurangnya kerjasama antara pegawai dalam memberikan pelayanan kepada masyarakat.

Oleh sebab itu, koordinasi dan komunikasi antara sesama pegawai harus memperoleh perhatian dari pimpinan dengan selalu memberikan pembinaan-pembinaan, pengarahanpengarahan sehingga para pegawai memahami pentingnya koordinasi dan komunikasi dalam menjalankan tugas pekerjaannya. Lebih dari itu, pimpinan pun harus berusaha memberikan contoh perilaku yang senantiasa berkoordinasi dan 
berkomunikasi dengan para pegawai, sehingga seluruh permasalahan yang timbul dapat dicari solusinya atau bahkan dapat mencegah timbulnya permasalahan baru.

\section{Pengawasan}

Berdasarkan akumulasi analisis hasil penelitian sebagaimana yang telah disajikan sebelumnya untuk indikator pengawasan diperoleh skor rata-rata sebesar 2,68. Nilai skor rata-rata ini apabila dimasukkan ke dalam skala range penilaian berada pada kategori sedang, berarti bahwa pengawasan dalam rangka menjalin kerjasama pegawai dalam memberikan pelayanan di Dinas Kependudukan dan Catatan Sipil Kabupaten Boalemo dinilai kurang.

Hal ini sesuai dengan pengamatan peneliti di lapangan, bahwa pengawasan yang dilakukan oleh pimpinan dalam rangka menjalin kerjasama pegawai dalam memberikan pelayanan masih kurang. Kurangnya pengawasan ini diperoleh melalui sistem pengawasan yang dijalankan kurang kontinyu, artinya pimpinan dalam mengawasi kerjasama para pegawai tidak melakukannya secara intens dan terus menerus, melainkan akan megawasi jika ada laporan dari pegawai mengenai satu permasalahan yang timbul. Demikian pula dalam melakukan pengawasan tersebut, pimpinan kurang objektif atas apa yang sebenarnya menjadi fokus untuk di awasi. Pengawasan yang selama ini dilakukan lebih pada pengawasan kehadiran pegawai, sementara menyangkut sikap kerja, hubungan kerja, maupun kerjasama secara keseluruhan dari para pegawai kurang mnejadi objek pengawasan pimpinan. Akibatnya para pegawai tidak merasa terpanggil untuk bekerjasama atau merasa bahwa kerjasama dengan pegawai lainnya bukalah hal yang penting untuk dilakukan. Sebagian besar pegawai berprinsip bahwa yang penting adalah menyelesaikan tupoksinya dengan tuntas.

Pengawasan sangat penting dilakukan pimpinan untuk menjamin seluruh fungsi organisasi berjalan sebagaimaa mestinya. Oleh sebab itu peningkatan kontinyuitas dan objektivitas pengawasan adalah hal penting yang harus diperhatikan dan dilakukan oleh pimpinan organisasi, agar kerjasama pegawai dalam memberikan pelayanan kepada masyarakat dapat terwujud sehingga akan mudah bagi organisasi mencapai tujuannya.

\section{SIMPULAN}

Berdasarkan hasil penelitian dan pembahasan yang telah diuraikan pada bab sebelumnya 
mengenai kerjasama pegawai dalam memberika pelayanan di Dinas Kependudukan dan Catatan Sipil Kabupaten Boalemo, maka diperoleh kesimpulan sebagai berikut:

1. Indikator motivasi diperoleh skor rata-rata sebesar 2,47 termasuk pada kategori sedang, berarti bahwa motivasi kerjasama pegawai dalam memberikan pelayanan dinilai kurang.

2. Indikator koordinasi dan komunikasi diperoleh skor ratarata sebesar 2,77 termasuk pada kategori sedang, berarti bahwa koordinasi dan komunikasi sebagai bentuk kerjasama pegawai dalam memberikan pelayanan dinilai kurang.

3. Indikator pengawasan diperoleh skor rata-rata sebesar 2,68 termasuk pada kategori sedang, berarti bahwa pengawasan kerjasama pegawai dalam memberikan pelayanan dinilai kurang.

4. Secara keseluruhan diperoleh skor rata-rata 2,64 dengan kategori sedang, berarti bahwa kerjasama pegawai dalam memberikan pelayanan di Dinas Kependudukan dan Catatan Sipil Kabupaten Boalemo dinilai kurang.

\section{SARAN}

Berdasarkan kesimpulan di atas mengenai kurangnya kerjasama pegawai dalam memberikan pelayanan di Dinas Kependudukan dan Catatan Sipil Kabupaten Boalemo, maka disarankan agar :

1. Perlu adanya penghargaan/ pengakuan atas prestasi kerja pegawai, pembinaan hubungan kerja sehingga pegawai termotivasi untuk bekerjasama dalam memberikan pelayanan.

2. Peran pimpinan sangat diperlukan untuk membangun koordinasi dan komunikasi antara sesama pegawai dalam memberikan pelayanan kepada masyarakat.

3. Objektivitas dan kontinuitas pelaksanaan pengawasan perlu ditingkatkan agar dapat diketahui atau dicegah setiap persolan yang timbul terutama menyangkut pelayanan kepada masyarakat.

\section{DAFTAR PUSTAKA}

Athoillah, H.M. Anton. Dr.MM. 2010.

Dasar-Dasar

Manajemen. Bandung: Pustaka Setia.

Bangun, Wilson. 2008. Intisari Manajemen. Cet. I. Bandung: Refika Aditama.

Fathoni, H. Abdurrahmat. 2006. Organisasi dan Manajemen 
Sumber Daya Manusia.

Jakarta: Rineka Cipta.

Hasibuan, H. Melayu. S.P. 2007.

Manajemen Sumber Daya

Manusia. Ed. Revisi. Jakarta:

Bumi Aksara.

Juliantara, Dadang. 2005.

Peningkatan Kapasitas

Pemerintah Daerah Dalam

Pelayanan Publik.

Yogyakarta: Pembaruan.

Kamus Besar Bahasa Indonesia, tahun1994 Jakarta: Deprtemen

Pendidikan dan Kebudayaan

Republik Indonesia,

Kurniawan, Agung. 2005.

Transformasi Pelayanan

Publik. Yogyakarta:

Pembaruan.

Lukman, Sampara. 1999.

Manajemen Kualitas Pelayaan.

Jakarta: STIA LAN Press.

Mangkunegara, A.A. Anwar Prabu.

2006. Evaluasi Kinerja Sumber

Daya Manusia (SDM).

Bandung: PT. Refika Aditama.

Panggabean, Mutiara S. 2004.

Manajemen Sumber Daya

Manusia. Jakarta: Ghalia

Indonesia.

Ratminto dan Winarsih, Atik Septi.

2009. Manajemen Pelayanan.

Yogyakarta: Pustaka Pelajar.

Setiabudi, Didit. 2008. Pelayanan

Publik. Jakarta: Bumi Aksara.
Siagian, Sondang P. 2008. Filsafat Administrasi, Ed.Revisi, Cet. V, Jakarta: Bumi Aksara.

Sihotang, A. 2007. Manajemen Sumber Daya Manusia. Jakarta: Paradnya Paramita.

Sinambela dkk, Lijan Poltak. 2008. Reformasi Pelayanan Publik, Jakarta: Bumi Aksara.

Sugiyono. 2003. Statistik Untuk Penelitian. Bandung: Alfabeta.

------2010. Metode Penelitian Kuantitatif Kualitatif dan $R \& D$, Ed. Revisi Cet. Ke -10 . Bandung: Alfabeta.

Syafiie, H Inu Kencana. 2006. Sistem Administrasi Negara Republik Indonesia (SANRI). Bandung: Bumi Aksara.

\section{Dokumen Lainnya:}

Keputusan Menteri Pendayagunaan

Aparatur

Negara

(KEPMENPAN) nomor 63

Tahun 2004 tentang Pedoman

Penyelenggaraan Pelayanan

Profil Dinas Kependudukan dan Catatan Sipil Kabupaten Boalemo, Tahun 2011. 